\title{
Grazer effects on prokaryotes and viruses in a freshwater microcosm experiment
}

\author{
T. Sime-Ngando ${ }^{1, *}$, A. S. Pradeep Ram ${ }^{1,2}$ \\ ${ }^{1}$ Laboratoire de Biologie des Protistes, Université Blaise Pascal (Clermont-Ferrand II), UMR CNRS 6023, \\ 63177 Aubière Cedex, France \\ ${ }^{2}$ Present address: Centre for Ecological Research, Kyoto University, 509-3 Otsuka, Kamitanakami-hirano, \\ Otsu 520-2113 Shiga, Japan
}

\begin{abstract}
We conducted a short-term course experiment using a size-fractionation approach to manipulate grazers and test for their effects on viral and prokaryotic standing stocks and activities and on prokaryotic community composition, as assessed by the FISH (fluorescence in situ hybridisation) method. Experimental samples were collected in the Sep Reservoir during severe P-limiting conditions. The presence of grazers in microcosms appeared to be a stimulating factor for prokaryotic growth and viral proliferation, likely through the related nutrient and substrate enrichments. About $60 \%$ of the total prokaryote abundance was detected by FISH, with a dominance of Eubacteria and beta-Proteobacteria throughout the experiment, i.e. in the presence and in the absence of grazers. The relative abundances of the minor phylotypes remained unchanged in the absence of grazers, but significantly increased with time when grazers were present, indicating a grazer-mediated reduction in resource competition in prokaryotic assemblages. However, grazer effects resulted in an apparently greater alteration of the bacterial size structure (i.e. the occurrence of large, grazing-resistant cells) than of the relative abundances of the phylotypes analysed. The main findings suggest that, at least on a short-term scale (i.e. $\leq 1$ prokaryotic net generation time): (1) There is a synergy between grazer, prokaryotic and viral activities in oligotrophic conditions, through a cascading effect from grazer-mediated resource enrichment, with (2) a higher impact on the prokaryotic size structure than on the relative abundances of the major phylotypes, and (3) a significant acquisition of competitive advantages by the less adundant phylotypes. These findings are discussed in light of the recent 'phage kills winner' theory.
\end{abstract}

KEY WORDS: Plankton · Lakes · Microcosms · Viruses · Prokaryotes · Community composition · Grazer effects $\cdot$ Microbial ecology

\section{INTRODUCTION}

Viruses are now recognised to be among the most conspicuous and abundant biological entities in aquatic ecosystems (reviewed in Fuhrman 1999, Wommack \& Colwell 2000, Sime-Ngando et al. 2003, Weinbauer 2004). They have no intrinsic metabolism and are entirely dependent on sensitive hosts for 'survival' and proliferation. Studies examining large data sets have revealed that heterotrophic bacteria form the major host reservoir for viruses in pelagic systems (Bettarel et al. 2004). A significant amount of energy and matter flows into these systems via heterotrophic bacteria, i.e. the key link between dissolved organic matter and the higher trophic levels. The fate of bacterial production in aquatic systems is determined mainly through bacterivory and bacteriolysis. Both processes could significantly influence the production of dissolved organic carbon and the recycling of nutrients (Bratbak et al. 1994, Wilhelm \& Suttle 1999), and could, thus, shape bacterial diversity (Hahn \& Höfle 2001, Weinbauer \& Rassoulzadegan 2004). At times losses of bacteria due to viral lysis are comparable to those from protistan grazing (Fuhrman \& Noble 1995, Steward et al. 1996, Pradeep Ram et al. 2005). Evidence from theoretical analysis (Pedrós-Alió et al. 
2000) and empirical field observations (Weinbauer \& Höfle 1998a, Bettarel et al. 2004) has shown that viral bacteriolysis generally is much higher than protistan bacterivory in particularly constraining environments, such as hypersaline or anoxic waters.

In contrast to protistan bacterivory (cf. Hahn \& Höfle 2001), few attempts have been made to analyse the potential effects of viral lysis on the prokaryotic community composition (PCC). Most of these attempts were mainly based on theoretical considerations. The 'phage kills winner' theory (Thingstad \& Lignell 1997, Thingstad 2000) hypothesises that viruses constantly keep the most resource-competitive populations in check, resulting in favourable conditions for the maintenance of microbial diversity. Viral-mediated processes such as lysogenic conversion (i.e. with acquisition of new metabolic and phenotypic traits) and horizontal transfer of genes (i.e. transduction), as well as the complexity of the lysis products, have also been recognised as potential shaping forces for microbial diversity (Weinbauer \& Rassoulzadegan 2004). Accordingly, the prediction, a priori, that virioplankton have an impact on the overall prokaryotic community structure and diversity seems reasonable, although few experimental data are available (cf. Šimek et al. 2001b, Schwalbach et al. 2004, Winter et al. 2004). A conservative view in this context would be to consider that the impact of viruses fluctuates with and thus depends on the ambient conditions, including nutrient and grazing environments as 2 significant conditions (Weinbauer et al. 2003).

Studies carried out in the Rimov Reservoir (Czech Republic) suggest that viral lysis shifted the PCC toward the enhancement of a specific lineage within the beta-Proteobacteria, with preliminary evidence showing that protistan grazing may stimulate the frequency of viral infection (Šimek et al. 2001b, Weinbauer et al. 2003). A significant correlation between viruses and protistan grazers has also been reported in the northern Adriatic Sea (Weinbauer \& Peduzzi 1995); this was attributed to the protistan selectively feeding on infected cells presumed to be larger in size than non-infected cells. Studies have also shown that protists can directly feed on free viruses in the plankton, although the transfer of carbon to the higher trophic levels via this activity was of minor importance (Gonzales \& Suttle 1993, Bettarel et al. 2005). There are thus many routes of interaction between grazers and viruses in pelagic systems. However, few studies have been sufficiently comprehensive to characterise these interactions and their effects on the PCC. Such conclusions would require experimental information beyond the available approximations from theoretical or empirical field data. In the present study, we used a simple size-fractionation approach to eliminate grazers from freshwater microcosms, in order to examine their effects on viral and prokaryotic standing stocks and activities and on the PCC, as assessed by the FISH (fluorescence in situ hybridisation) method. We wanted to address 2 main questions: (1) Does a synergy exist between grazing and viral infection of bacteria? (2) What are the effects of grazers and/or of viral lysis on the PCC?

\section{MATERIALS AND METHODS}

Study site and sampling. Our experiment was conducted using water samples from the Sep Reservoir located in the French Massif Central $\left(46^{\circ} \mathrm{N}, 3^{\circ} \mathrm{E}\right)$. At its full supply level, the reservoir contains $4.7 \times 10^{6} \mathrm{~m}^{3}$ of water and has a surface area of $33 \mathrm{ha}$, with a maximum depth of $37 \mathrm{~m}$. For more details on the characteristics of the Sep Reservoir, see Jugnia et al. (1999) and Tadonléké et al. (2000). Triplicate microbial samples (i.e. $<200 \mu \mathrm{m}$ ) for experiments were collected in the deepest central point of the reservoir, at $5 \mathrm{~m}$ depth on July 23, 2003, at 10:00 h, by filling 251 Nalgene carboys, which had been previously washed with $1.2 \mathrm{~N} \mathrm{HCl}$ and rinsed 3 times with Milli-Q water and with the appropriate replicates. The sampling period corresponded to a clear-water phase, with a euphotic depth at about $6 \mathrm{~m}$ (estimated from the Secchi depth, Pradeep Ram et al. 2005).

Size fractionation. Immediately after sampling and for each replicate, half of the experimental microbial samples were filtered separately through Nuclepore Track Etch Membranes (0.8 $\mu \mathrm{m}$ pore size) under attenuated light conditions and low differential pressure ( $<50 \mathrm{~mm} \mathrm{Hg}$ ) to yield the 'grazer-free' or filtered treatment. We decided to use the second halves of the experimental samples (i.e. $<200 \mu \mathrm{m}$ ) as the unfiltered treatment, i.e. with grazers present, because preliminary tests clearly showed that bacterivory was significantly higher in these samples compared to the $<5 \mu \mathrm{m}$ filtered samples considered the grazer-enhanced treatment in similar studies (Šimek et al. 2001b, Weinbauer et al. 2003, Hornak et al. 2005).

The filtered and unfiltered treatments (i.e. 2 treatments $\times 3$ replicates) were acclimated for $1 \mathrm{~h}$ in the dark at in situ conditions, in $10 \mathrm{l}$ polycarbonate bottles that had been previously washed with $1.2 \mathrm{~N} \mathrm{HCl}$ and rinsed 3 times with Milli-Q water and with the appropriate experimental samples. Subsamples were then taken from each replicate at $\mathrm{t} 0, \mathrm{t} 3, \mathrm{t} 6, \mathrm{t} 12, \mathrm{t} 24, \mathrm{t} 36$ and t48 $\mathrm{h}$ for prokaryotic and viral abundances and activities, and at t0, t24, t36 and $448 \mathrm{~h}$ for PCC analysis. In addition, nutrient and chlorophyll a concentrations were analysed in the unfiltered replicates at to for the initial experimental conditions. 
Physicochemical analysis. The water temperature and dissolved oxygen were measured in situ with a WTW OXI 197 multiparametric probe. Samples for initial nutrient concentrations, namely dissolved ammonium $\left(\mathrm{NH}_{4}-\mathrm{N}\right)$, nitrate $\left(\mathrm{NO}_{3}-\mathrm{N}\right)$ and nitrite $\left(\mathrm{NO}_{2}\right.$ $\mathrm{N})$, nitrogen and soluble orthophosphate $\left(\mathrm{PO}_{4}-\mathrm{P}\right)$ and total phosphorus (TP) were analysed spectrophotometrically using standard methods (APHA 1985). The initial chlorophyll a concentration (chl) was determined spectrophotometrically from samples $(500 \mathrm{ml})$ collected on Whatman GF/F filters. Pigments were extracted in $90 \%$ acetone overnight in the dark at $4^{\circ} \mathrm{C}$, and concentrations were calculated from SCORUNESCO (1966) equations.

Prokaryotic and viral abundances. For viral (VA) and prokaryotic (PA) abundances, water samples were fixed with $0.02 \mu \mathrm{m}$ filtered buffered alkaline formalin (final concentration $2 \% \mathrm{v} / \mathrm{v}$ ). Immediately after sampling, subsamples ( 1 to $2 \mathrm{ml})$ were filtered $(<15 \mathrm{kPa}$ vacuum) through Anodisc filters (0.02 $\mu \mathrm{m}$ pore size, Whatman), using cellulose acetate backing filters (1.2 $\mathrm{m}$ pore size). Following staining with SYBR Green I fluorochrome (Molecular Probes) (final dilution, $2.5 \times 10^{-3}$-fold), as described by Noble \& Fuhrman (1998), filters were air dried on absorbent paper and mounted between a slide and glass cover slip with a special antifading mountant. The mounting medium Citifluor (Citifluor, London, UK) was amended with ca. $20 \%(\mathrm{v} / \mathrm{v})$ of Vecta Shield (Vector Laboratories). This modification significantly reduced fading of the fluorochrome and gave highly stable fluorescence. When not analysed immediately, slides were stored at $-20^{\circ} \mathrm{C}$ until counting under an epifluorescent microscope (LEICA DC 300F model). Prokaryotes were distinguished from virus-like particles on the basis of their relative size and brightness. A blank was routinely examined to control for contamination of the equipment and reagents. For prokaryotic counts, cells longer than $4 \mu \mathrm{m}$ (i.e. filamentous cells) and flocs were monitored separately and considered as grazing-resistant forms (Šimek et al. 1999, 2001a,b, 2003, Hornak et al. 2005). Specific growth rate (SGR) was calculated as the slope of the log-transformed prokaryotic numbers over time during the exponential growth phase.

Prokaryotic production. Prokaryotic production (PP) was determined by the incorporation of labelled thymidine ( $\left.{ }^{3} \mathrm{H}-\mathrm{TdR}\right)$ into DNA (Fuhrman \& Azam 1982). Then, $10 \mathrm{ml}$ of subsamples (in triplicate for each experimental replicate) and $0.5 \mathrm{~N} \mathrm{NaOH}$ killed controls were inoculated with labelled thymidine (specific activity $=87 \mathrm{Ci} \mathrm{mmol}^{-1}$, Amersham Biosciences) at a final concentration of $20 \mathrm{nM}$ in Pyrex tubes, and then incubated at in situ conditions and in the dark for $40 \mathrm{~min}$. TdR incorporation was stopped by adding $5 \mathrm{~N}$ $\mathrm{NaOH}$. Radioactive samples were filtered though
$0.2 \mu \mathrm{m}$ cellulose acetate filters (Sartorius), and rinsed twice with $3 \mathrm{ml}$ ice cold $5 \%$ trichloroacetic acid. Filters were placed in vials, allowed to dry and solubilised with $0.5 \mathrm{ml}$ of ethyl acetate. After adding $5 \mathrm{ml}$ of scintillation cocktail, radioactivity was determined with a liquid scintillation counter (Beckman, LS 6500). Prokaryotic production was calculated in moles of TdR incorporated into DNA.

Phage bacteriolysis. In formalin-fixed samples, bacteria contained in $8 \mathrm{ml}$ subsamples were harvested by ultracentrifugation onto 400 mesh copper electron microscope grids with carbon-coated Formvar film using a Centrikon TST 41.14 swing-out rotor at $70000 \times g$ for $20 \mathrm{~min}$ at $4^{\circ} \mathrm{C}$ (Bettarel et al. 2004). Each grid was then stained for $30 \mathrm{~s}$ with uranyl acetate $(2 \%$ w/w) and examined in a JEOL 1200EX transmission electron microscope operated at $80 \mathrm{kV}$ at magnifications of 20000 to $40000 \times$. At least 300 to 500 prokaryotic cells per sample were examined to determine the frequency of visibly infected cells (FVIC). Cells were scored as infected if they contained 5 or more intracellular viruses. Because mature phages are visible only late in the infection cycle, FVIC counts were converted to the frequency of infected cells (FIC) using the equation FIC $=9.524$ FVIC -3.256 (Weinbauer et al. 2002).

Prokaryotic community composition. The PCC was analysed by in situ hybridisation using 5 different probes that were fluorescently labelled with the indocarbocyanine dye Cy3 (MWG-Biotech). Two labelled oligonucleotides included the domain-specific probes EUB338 for Eubacteria (Amann et al. 1990) and ARCH915 for Archaea (Stahl \& Amann 1991). The group-specific probes ALF1b and BETA42a (Manz et al. 1992) were used to detect alpha and beta subclasses of Proteobacteria. Finally, the probe CF319a was used to detect members of the Cytophaga-Flavobacterium cluster of the Cytophaga-Flavobacterium-Bacteroides phylum (Manz et al. 1996). Throughout the text, these bacterial groups are designated as EUB, ARCH, ALF, BETA and CF, respectively. They were analysed according to Glöckner et al. (1999).

Briefly, 4 to $6 \mathrm{ml}$ of water subsamples were concentrated on polycarbonate filters $(25 \mathrm{~mm}, 0.2 \mu \mathrm{m}$ pore size, Millipore) by applying a low vacuum. The bacteria on filters were subsequently fixed by overlying with $4 \%$ paraformaldehyde in phosphate-buffered saline (PBS; pH 7.2) and stored at $-20^{\circ} \mathrm{C}$ until analysis. For each subsample, 2 filters were prepared, one for EUB and the second one was cut into 4 sections prior to hybridisation with the other probes. All hybridisations were performed at $46^{\circ} \mathrm{C}$ for $90 \mathrm{~min}$. After hybridisation, the probed prokaryotes were stained with DAPI (final concentration: $4 \mu \mathrm{g} \mathrm{ml}^{-1}$ ) and mounted between a slide and a glass cover slip as described previously for 
PA and VA. Hybridised cells were then enumerated using the LEICA epifluorescence microscope $(1250 \times)$ equipped with optical filters for UV (DAPI) and green excitation (Cy3).

Statistical analysis. Differences in prokaryotic and viral parameters between treatments were tested by 1-way ANOVA. The null hypothesis was that there was no significant difference between filtered and unfiltered treatments. Potential relationships among various measured variables were tested by Pearson's correlation analysis. All statistical analyses were performed using Minitab's software for Windows (Release 12, Minitab).

\section{RESULTS}

\section{Experimental environment}

Table 1 lists the initial physico-chemical and biological characteristics of the experimental samples. For all these variables, the within-sample variability was judged satisfactory, with coefficients of variation always $<15 \%$ and standard deviations most of the time lower than the detection limits of the methods (cf. Wetzel \& Likens 1995). In the euphotic layer, temperature was at its warmest annual level and oxygenic conditions prevailed with a dissolved oxygen content $>6 \mathrm{mg} \mathrm{l}^{-1}$ (Pradeep Ram et al. 2005). This contrasts with an apparent constraining environment in terms of the availability of conservative nutrients. The

Table 1. Mean $( \pm$ SD for triplicates) surface water characteristics of the Sep Reservoir during the experimental study

\begin{tabular}{|c|c|}
\hline Parameter (units) & Values \\
\hline Temperature $\left({ }^{\circ} \mathrm{C}\right)$ & $25.1 \pm 0.1^{\mathrm{a}}$ \\
\hline Dissolved oxygen $\left(\mathrm{mg} \mathrm{l}^{-1}\right)$ & $10.1 \pm 0.05^{\mathrm{a}}$ \\
\hline $\mathrm{NH}_{4}-\mathrm{N}\left(\mathrm{mg} \mathrm{l}^{-1}\right)$ & $0.06 \pm 0.005$ \\
\hline $\mathrm{NO}_{2}-\mathrm{N}\left(\mathrm{mg} \mathrm{l}^{-1}\right)$ & $0.02 \pm 0.003$ \\
\hline $\mathrm{NO}_{3}-\mathrm{N}\left(\mathrm{mg} \mathrm{l}^{-1}\right)$ & $0.70 \pm 0.02$ \\
\hline $\mathrm{P}_{-}-\mathrm{PO}_{4}\left(\mathrm{mg} \mathrm{l}^{-1}\right)$ & $0.01 \pm 0.001$ \\
\hline Total phosphorus $\left(\mathrm{mg} \mathrm{l}^{-1}\right.$ ) & $0.35 \pm 0.03$ \\
\hline Chlorophyll a $\left({\left.\mu \mathrm{g} \mathrm{l}^{-1}\right)}^{-1}\right.$ & $9.9 \pm 1.2$ \\
\hline Prokaryotic total abundance $\left(\times 10^{6}\right.$ cells $\left.\mathrm{ml}^{-1}\right)$ & $3.7 \pm 0.3$ \\
\hline Eubacteria (\%) & $56.3 \pm 7.3^{\mathrm{b}}$ \\
\hline Beta-Proteobacteria (\%) & $20.5 \pm 2.2^{\mathrm{b}}$ \\
\hline Alpha-Proteobacteria (\%) & $2.0 \pm 0.3^{b}$ \\
\hline Cytophaga-Flavobacterium (\%) & $2.0 \pm 0.2^{\mathrm{b}}$ \\
\hline Archaea (\%) & $3.8 \pm 0.2^{\mathrm{b}}$ \\
\hline Prokaryotic production (pmol $\mathrm{l}^{-1} \mathrm{~h}^{-1}$ ) & $24.8 \pm 2.6$ \\
\hline Viral abundance $\left(\times 10^{6} \mathrm{ml}^{-1}\right)$ & $12.6 \pm 0.6$ \\
\hline Frequency of infected bacterial cells (\%) & $15.41 \pm 1.14$ \\
\hline \multicolumn{2}{|c|}{$\begin{array}{l}\text { aMean value for the euphotic depth (i.e. } 0 \text { to } 6 \mathrm{~m} \text {, Pradeep } \\
\text { Ram et al. 2005) } \\
\text { bPercentage of total prokaryotic abundance }\end{array}$} \\
\hline
\end{tabular}

very low concentration of dissolved inorganic phosphate and the related high N:P atomic ratio (ca. 35:1) indeed indicated P-limiting conditions, typical of the Sep Reservoir during summer (Tadonléké et al. 2000, 2002). In terms of the biological environment, the experimental samples contained about $10 \mathrm{\mu g} \mathrm{l}^{-1}$ of chlorophyll a pigment, which is at the lower end of the annual range (i.e. 1 to $43 \mu \mathrm{g} \mathrm{l}^{-1}$ ) recorded in the euphotic layer during the study year (Pradeep Ram et al. 2005). The prokaryotic community was dominated by EUB, which constituted $56 \%$ of the total abundance of $3.7 \times 10^{6}$ cells $\mathrm{ml}^{-1}$, at a total thymidine incorporation rate of $24.8 \mathrm{pmol}^{-1} \mathrm{~h}^{-1}$. Within the EUB, the BETA subclass was the dominant group (21\%), while cells hybridising with ALF and CF and with ARCH probes were $<4 \%$ of the total abundance. The viral abundance at the start of the experiment was roughly 3 -fold higher than the prokaryotic abundance (Table 1).

\section{Effects of filtration}

In the t0 samples, the prokaryotic and viral variables under study were similar in unfiltered and filtered treatments (ANOVA, p > 0.05). VA and FIC were, respectively, at $12.60 \pm 0.60 \times 10^{6}$ viruses $\mathrm{ml}^{-1}$ and $15.41 \pm 1.14 \%$ in the unfiltered treatment and at $12.20 \pm 0.40 \times 10^{6}$ viruses $\mathrm{ml}^{-1}$ and $15.31 \pm 1.10 \%$ in the filtered treatment. PA and PP averaged, respectively, $3.7 \pm 0.3 \times 10^{6}$ cells ml ${ }^{-1}$ and $24.82 \pm 2.55 \mathrm{pmol} \mathrm{l}^{-1} \mathrm{~h}^{-1}$ in unfiltered replicates and $3.5 \pm 0.4 \times 10^{6}$ cells ml ${ }^{-1}$ and $23.32 \pm 1.90 \mathrm{pmol} \mathrm{l}^{-1} \mathrm{~h}^{-1}$ in filtered replicates. Similarly, the PCC did not show any significant differences among treatments at $\mathrm{t} 0$, although the relative abundance of ALF was notably lower in the filtered treatment.

\section{Viral abundance and activity}

In the unfiltered treatment, VA and FIC both increased almost linearly from t0 to $\mathrm{t} 36$, when the highest number of viruses $\left(17.4 \times 10^{6} \mathrm{ml}^{-1}\right)$ and FIC $(20.7 \%)$ were recorded (Fig. 1). Both variables were significantly correlated $(\mathrm{r}=0.64, \mathrm{p}<0.001)$. In the filtered treatment, VA and FIC were significantly (ANOVA, $\mathrm{p}<0.01)$ lower than in the unfiltered treatment, this being related to the trend during the last $24 \mathrm{~h}$ of incubation for VA and from $\mathrm{t} 3$ towards the end of the incubation for FIC. Indeed, marked differences in the temporal trends were observed between the 2 treatments. In the filtered treatment, VA increased to some extent within the first $24 \mathrm{~h}$ of incubation, while FIC dropped from 15.31 to $7.31 \%$ between t0 and $\mathrm{t} 3$ and 

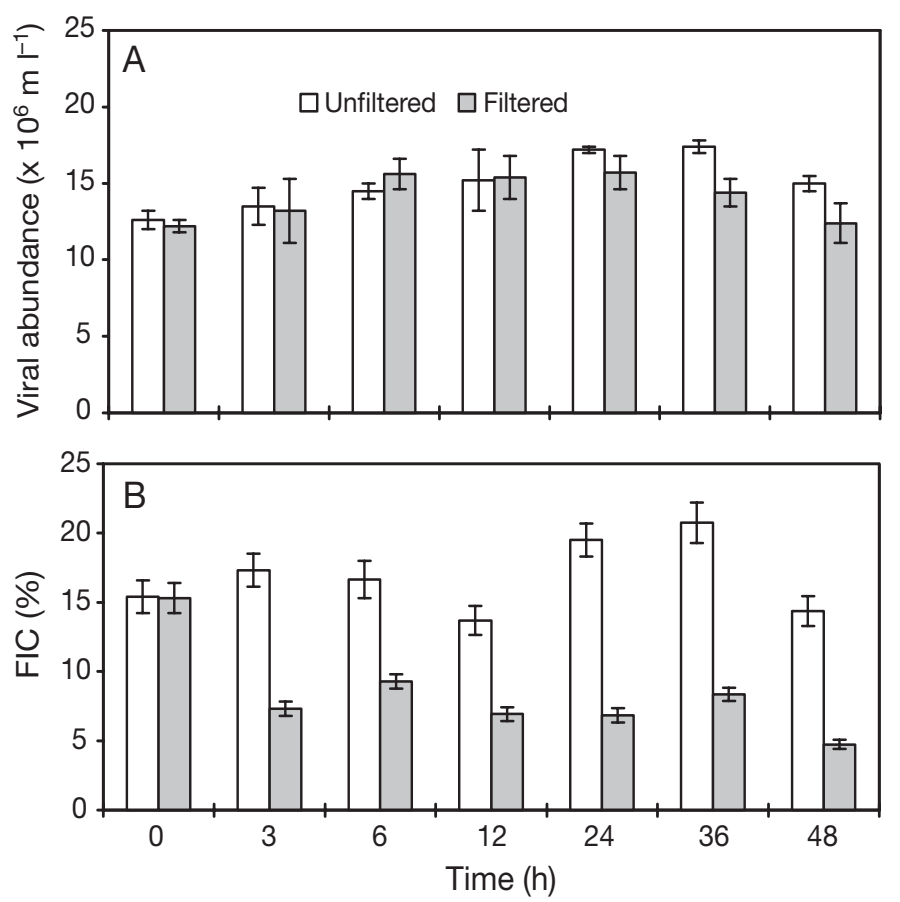

Fig. 1. Time-course changes in viral abundance and frequency of infected bacterial cells (FIC) in the presence (unfiltered, i.e. $<200 \mu \mathrm{m}$ size fraction) and absence (filtered, i.e. $<0.8 \mu \mathrm{m}$ size fraction) of grazers. Values are means of triplicate samples, and vertical bars show $\pm \mathrm{SD}$

then fluctuated slightly around $7 \%$ untill t36. The apparent decrease in the viral parameters within the last $12 \mathrm{~h}$ of incubation was characteristic of the 2 treatments.

\section{Prokaryotic abundance and productivity}

In the unfiltered treatment, changes in PA and PP (Fig. 2) during incubation were similar to those observed in VA and FIC, with a general increasing trend. These variables were significantly correlated to each other $(r>0.70, p<0.001)$. The SGR of the prokaryotic community was at $0.5 \pm 0.2 \mathrm{~d}^{-1}$ (i.e. between $\mathrm{t} 0$ and $\mathrm{t} 48$ ). In the filtered treatment, PA also increased between $\mathrm{t} 0$ and $\mathrm{t} 36$, the apparent generation time ( $\mathrm{SGR}=0.3 \pm 0.1 \mathrm{~d}^{-1}$ ) being significantly longer despite the absence of grazers. The thymidine incorporation rate (i.e. PP) in the filtered treatment was rather heterogeneous and independent of that in PA, although substantial increases were noted from t0 to t6 and from $\mathrm{t} 36$ to 448 (Fig. 2B). As for viruses, PA and PP were significantly (ANOVA, $p<0.05$ ) higher in the unfiltered than in the filtered treatment, due to differences noted from $\mathrm{t} 12$ onwards for PA and from t12 to t36 for PP.
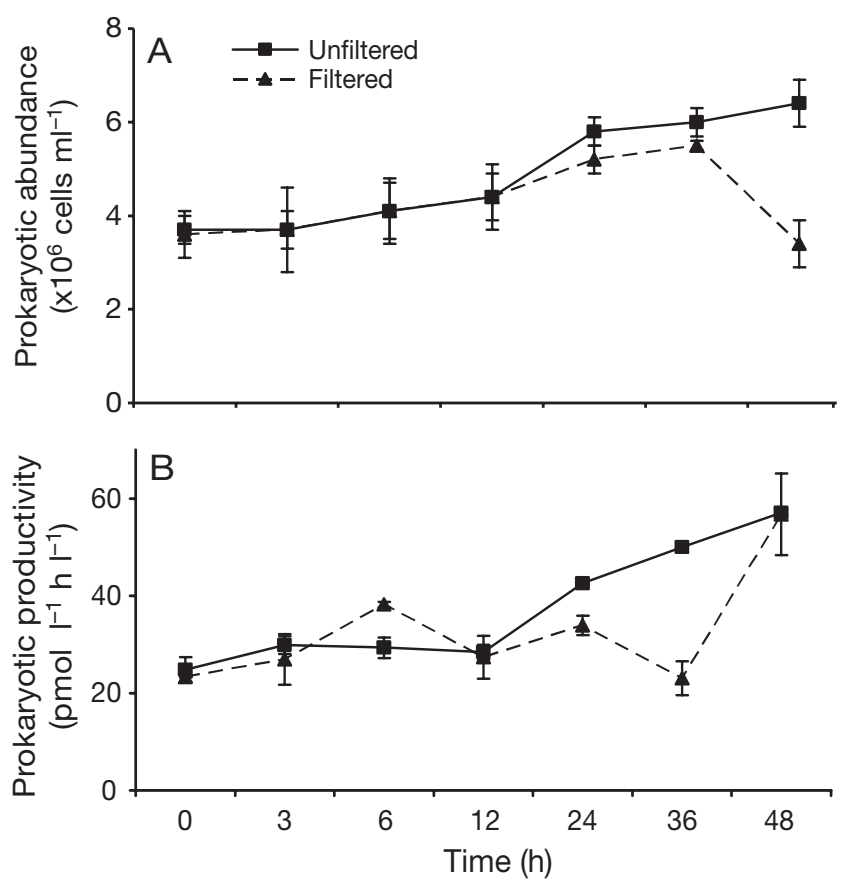

Fig. 2. Time-course changes in prokaryotic abundance and productivity (assayed via incorporation of radioactive thymidine) in the presence (unfiltered, i.e. $<200 \mu \mathrm{m}$ size fraction) and absence (filtered, i.e. $<0.8 \mu \mathrm{m}$ size fraction) of grazers. Values are means of triplicate samples, and vertical bars show $\pm \mathrm{SD}$

\section{Prokaryotic community composition}

In the 2 treatments and throughout the incubation period, PCC was dominated by EUB, which included the BETA subclass as the dominant group. Shifts in the PCC were obvious only after t24 in both treatments (Fig. 3). In the 2 treatments, these shifts were similar but non-significant (ANOVA, $p>0.05$ ) for the dominant EUB and BETA groups, which decreased in relative abundances till $\mathrm{t} 36$ and then increased within the last $12 \mathrm{~h}$ of incubation. For the minor bacterial groups, $\mathrm{CF}, \mathrm{ARCH}$ and ALF in the unfiltered fraction significantly increased (ANOVA, $p<0.05)$ towards the end of the incubation time, by $2.0-, 1.7$ - and 1.5 -fold, respectively. No apparent trend was noted in the filtered fraction in which the relative abundances of ALF, CF and ARCH remained similar (ANOVA, $p>0.05$ ) throughout the experiment (Fig. 3).

During incubation, the relative numbers of filamentous and floc-forming bacteria in the unfiltered treatment gradually increased with PP $(r>0.7, p<0.01)$, this being apparently faster for filamentous (SGR $=0.27 \mathrm{~d}^{-1}$ ) than for floc-forming $\left(\mathrm{SGR}=0.19 \mathrm{~d}^{-1}\right)$ populations (Fig. 4). Filamentous and floc-forming bacterial cells were dominated mostly by the CF phylotype and, to a lesser degree, by the BETA subgroup. None of these 'giant' cells were recorded in the filtered treatment. 


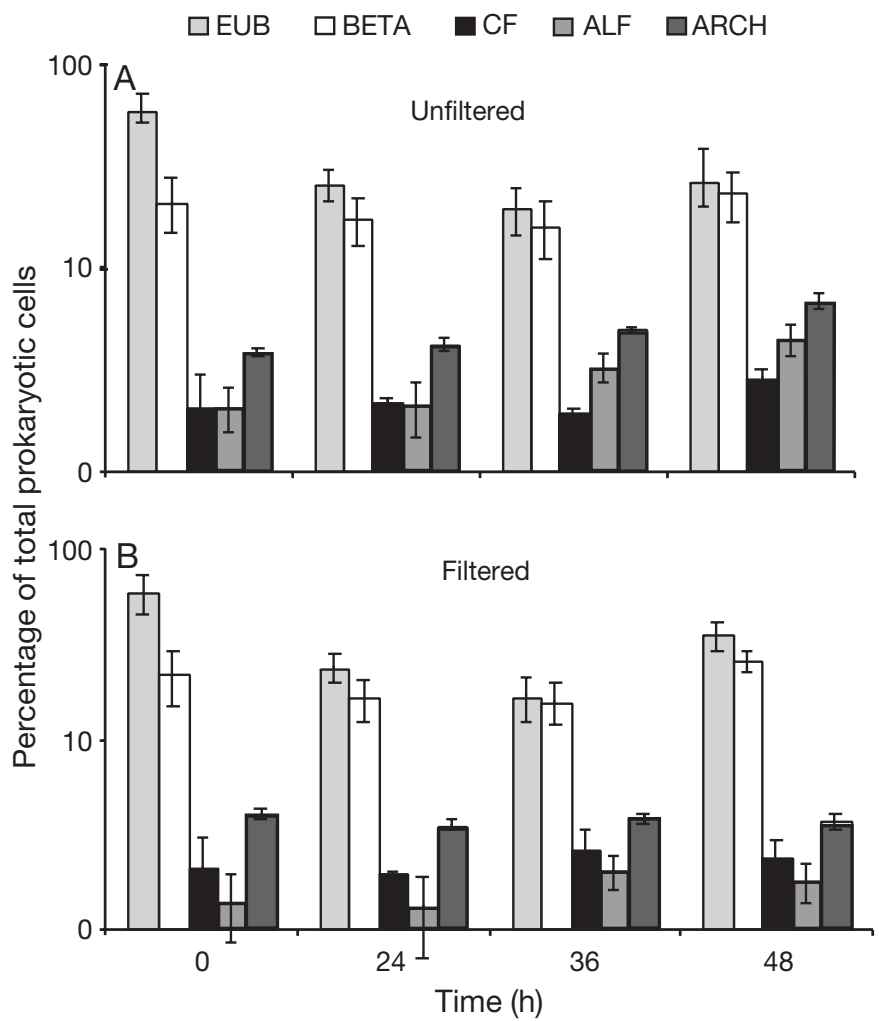

Fig. 3. Time-course changes in relative abundances of FISHtargeted Eubacteria (EUB), alpha-Proteobacteria (ALF) and beta-Proteobacteria (BETA), the Cytophaga-Flavobacterium cluster (CF) and Archaea (ARCH) in (A) the presence (unfiltered, i.e. $<200 \mu \mathrm{m}$ size fraction) and (B) the absence filtered, i.e. $<0.8 \mu \mathrm{m}$ size fraction) of grazers. Values are means of triplicate samples, and vertical bars show $\pm \mathrm{SD}$

\section{DISCUSSION}

From the comparisons of raw microbial and filtered treatments before incubations (ANOVA, $p>0.05$ ), we concluded that the manipulation of experimental samples yielded no immediate significant effect on the viral and bacterial variables under study, including the members of the CF cluster, which are often associated with aggregates (Weiss et al. 1996, Kirchman 2002). In addition, for none of the subsamples taken during the $48 \mathrm{~h}$ incubation period in the microcosms, were we able to detect the presence of micrograzers in the filtered treatment. Size fractionation of the water samples through $0.8 \mu \mathrm{m}$ filters suggested the dominance $(>90 \%)$ of free-living bacteria in the natural assemblages under study, as previously reported for the Sep Reservoir (Jugnia et al. 1999). Previous studies of this reservoir have also revealed that, in contrast to most pelagic systems (Strom 2000), heterotrophic nanoflagellates contribute less (usually $<30 \%$ of total mortality) to bacterial mortality in this area, the main agents for bacterial mortality being microzooplankton,

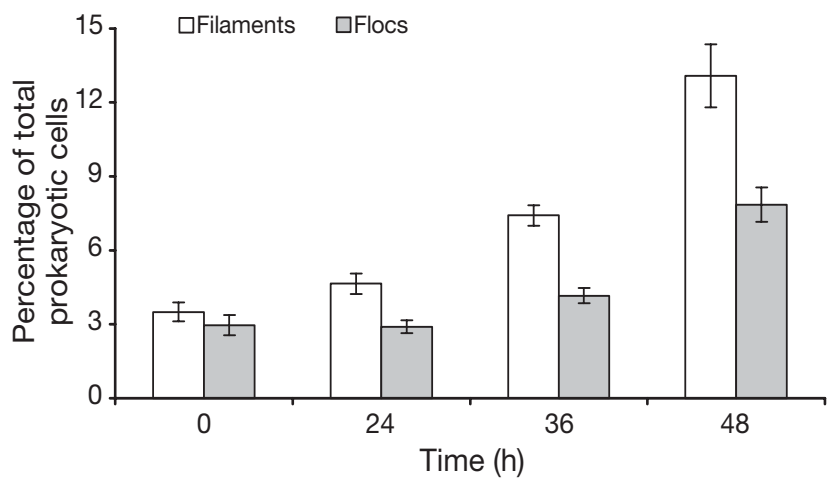

Fig. 4. Changes in the proportions of filament and flocforming bacteria exposed to grazing pressure (unfiltered treatment). Values are means of triplicate samples, and vertical bars show \pm SD

which account for about $60 \%$ of the seasonal predation on bacteria (Jardillier et al. 2004, Pradeep Ram et al. 2005). Indeed, preliminary tests before our experiments clearly showed that bacterivory was largely and significantly higher in raw microbial samples (i.e. $<200 \mu \mathrm{m}$ ) compared to $<5 \mu \mathrm{m}$ filtered samples (data not shown). This prevented us from preparing our grazer-positive treatment from $<5 \mu \mathrm{m}$ filtered samples, the so-called grazer-enhanced treatment in other studies (Šimek et al. 1999, 2001b, 2003, Weinbauer et al. 2003, Hornak et al. 2005).

In general, shifts in bacterial and viral variables within the $2 \mathrm{~d}$ of incubations were significantly smaller in the $0.8 \mu \mathrm{m}$ filtered than in the unfiltered treatments, relative to the initial conditions, corroborating the observation reported for viruses from the Rimov Reservoir (see Fig. 6 in Šimek et al. 2001b). In the Sep Reservoir, this probably reflects the fact that bacterial net growth (i.e. excluding respiration and mortality) during the $48 \mathrm{~h}$ experiment spanned about two-thirds of a generation in the manipulated samples and 1 generation in the raw microbial samples. Microbial processes were thus going on but rather slowly in filtered compared to unfiltered treatments, partly because of the mechanistic but non-significant effects of filtration. Together with the pulse increases noted in PP and the uncoupling between prokaryotes and viruses, this also suggests that substrate and nutrient enrichment following filtration was negligible. For prokaryotic and viral standing stocks and activities recorded following the initial sampling, data from replicates were generally more similar to each other than to data from 2 nearby points on the charts from the filtered treatment. Had no lytic infection occurred in this treatment, viral abundances would have declined rapidly (Schwalbach et al. 2004). In addition, VA and FIC levels were substantial but lower relative to the unfiltered treatment, indicating that lysogeny was not a significant source of 
virus production in the filtered treatment. We thus believe that viral lytic activity only assumed a small role in regulating the bacterial community in the absence of grazers.

In sharp contrast to the filtered treatment, VA, FIC, $\mathrm{PA}$ and $\mathrm{PP}$ in the unfiltered treatment generally increased after t12 and were correlated to each other, corroborating the observations made on a seasonal basis in the Sep Reservoir (Pradeep Ram et al. 2005), and in other lakes in the same region as well (Bettarel et al. 2004). These variables were also significantly higher in the unfiltered than in the filtered samples, due to the differences noted at least $3 \mathrm{~h}$ following the beginning of the incubations. The above findings imply 2 mutually exclusive hypotheses: (1) the intrinsic metabolic rates of the main potential host (i.e. bacteria) of viral proliferation were stimulated in the presence of grazers, or (2) the occurrence of a 3 to $24 \mathrm{~h}$ delayed inhibition of these rates was due to the mechanistic effect of filtration. We have already rejected the latter hypothesis (see above). Thus, it seems that prokaryotes grew faster in the presence of grazers, resulting in a tight functional coupling between prokaryotic and viral communities (i.e. viral loop). The grazer stimulation of viral proliferation was first reported by Šimek et al. (2001b) for the Rimov Reservoir. Šimek and coauthors speculated that given the fact that bacterial cell-specific production and activity are stimulated by grazing (Posch et al. 1999), higher growth rates might be associated with enhanced receptor formation on the cell surface, which may result in a greater chance of phage attachment and thus higher infection frequencies.

The mechanism behind an apparent synergy between grazing and viral lysis via the prokaryotic compartment is still unclear. In our study, it was difficult to directly address the interactions between viruses and prokaryotes, as both were present in our experimental treatments, but the nutrient environment was undoubtedly a significant factor in these interactions. Our experiment was carried out during a clearwater phase, following the apparent exhaustion of phosphorus in the reservoir (Pradeep Ram et al. 2005). The N:P ratio in the experimental samples was very high, characteristic of the typically severe P-limiting conditions in the Sep Reservoir during summer (Tadonléké et al. 2000, 2002). In our unfiltered treatment, prokaryotic growth was likely forced by regenerated nutrients and labile organic substrates from grazer activity. Experimental evidence for this has recently been provided for the Rimov Reservoir, where coupling between bacteria and viruses due to nutrient enrichment was significantly stronger than the stimulation of viral lysis induced by grazing alone (Weinbauer et al. 2003). Micrograzers are known to efficiently regenerate inorganic nutrients that are essential for maintaining biological activity in aquatic systems (Strom 2000). They are also recognised as the main producers of dissolved organic matter (DOM) for bacterial growth in oligotrophic systems (Nagata 2000). Several processes like sloppy feeding, excretion, egestion and release of faecal pellets from zooplankton could also lead to nutrient regeneration. Since previous studies have suggested the prevalence of microbial cycling of matter in the Sep Reservoir during summer (Jugnia et al. 1999, Tadonléké et al. 2002), the physical separation of bacteria and grazers will have a strong effect on nutrient availability. This certainly would have an impact on the abundance and activity of viruses, as bacteria are the main hosts for viral proliferation in this reservoir (Pradeep Ram et al. 2005). We hypothesise that among the regenerated nutrients, $\mathrm{P}$ was the most important in the enhancement of bacterioplankton growth in the presence of grazers during our experiments. This could have a significant influence on nutrient cycling and the DOM-bacterial-viral loop, and on the PCC as well.

In this study, about $60 \%$ of the total prokaryotic abundance was detected by FISH, which is slightly lower than the detection possible in other oligotrophic and mesotrophic ecosystems (Glöckner et al. 1996). This suggests that some typical freshwater groups, like Actinobacteria (Glöckner et al. 2000), could also be important in the Sep Reservoir. Among the targeted groups, EUB and the related subgroup of BETA were quantitatively dominant, corroborating a recent finding for the Sep Reservoir (Jardillier et al. 2004) and other freshwater systems (Glöckner et al. 2000, Hornak et al. 2005). These bacterial phylotypes probably harboured a higher rRNA-targeted content and contributed significantly to the faster growing and highly active fractions in the bacterioplankton. However, the observed changes during incubation were similar in the 2 experimental treatments. From a recent experiment in the Rimov Reservoir, BETA bacteria also showed the ability to outgrow the other groups of bacteria under either reduced/absence or enhanced/presence of grazers and viruses, with low response to size fractionation (Hornak et al. 2005). In general, when only relative abundances of phylogenetic groups of prokaryotes targeted by few group-specific probes are considered, the FISH technique may reveal only a very few changes in PCC. Although, we did observe significant changes in the less abundant phylotypes, i.e. $\mathrm{ALF}, \mathrm{CF}$ and $\mathrm{ARCH}$, which represented $<4 \%$ of the total cell abundance in the t0 samples. The oligoFISH probe used for ARCH (i.e. ARCH915) may be unspecific (Pernthaler et al. 2002, Brinkmeyer et al. 2004), suggesting that archeal abundance may be overestimated in this study. Accordingly, the significant changes noted for the minor phylotypes, i.e. for at least 


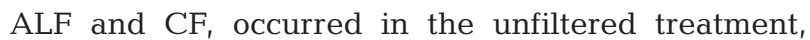
where the relative abundances increased during incubations, extending grazer effects noted for the standing stocks and activities to the PCC. Interestingly, in addition to the stimulation of bacterial growth and the related viral lysis, the suggested input of nutrients and substrates from grazing and lysis activities may also have released the competition pressure within the prokaryotic community, thereby increasing the competitiveness of the minor phylotypes.

The increase of filamentous and floc-forming bacteria in the unfiltered treatment was mainly due to the CF and, to a lesser degree, to the BETA members, similar to observations reported in other freshwater bodies, where grazing-resistant cells occurred mainly in these lineages (Šimek et al. 2001b, Hornak et al. 2005). The capability of natural bacteria to change their size structure in response to grazing pressure is widespread among different phylogenetic groups (Hahn \& Höfle 2001, Šimek et al. 2001b, Langenheder \& Jürgens 2001). In our study, no filamentous forms were found with mature intracellular viruses. This has previously been reported for the Rimov Reservoir (Šimek et al. 2001b) and for the surface waters of Lake Plußsee (Weinbauer \& Höfle 1998b), indicating that filamentous bacteria are not only resistant to grazing but also to viral infections. As this group represented $<15 \%$ of the total prokaryotic abundance, the absence of mature phages in these bacteria may also be attributed to the low number of filamentous forms observable by the FVIC technique used in this study. The correlations between the relative numbers of grazingresistant cells and the PP implied that these cells were the active forms contributing to the high biomass production during incubations, despite their low numerical proportions. The impact of grazer effects on bacterial size structure (i.e. biomass distribution) was, thus, apparently higher than on the relative cell numbers of the different phylotypes (Šimek et al. 2001b, Hornak et al. 2005).

Finally, the main findings reported in this short-term study may seem at variance with the 'phage kills winner' (PKW) theory according to which viruses constantly keep the most resource-competitive populations (i.e. the most abundant) in check, resulting in favourable conditions for the maintenance of microbial diversity (Thingstad \& Lignell 1997, Thingstad 2000). As referenced in Schwalbach et al. (2004), the PKW theory has been partially tested in chemostat and culture studies, where the 'survival' of viruses was highly dependant on the less-abundant, sensitive bacterial cells, despite the majority of the cells being resistant to viral infection. Schwalbach and coauthors then suggest that there may be a relatively stable coexistence between the dominant bacteria and their viruses, and that each bacterial species may exist in both a virussensitive and virus-resistant form. Indeed, besides the comprehensive paradox that the winner is the one who is killed', the PKW theory implies that the relative abundances are the best descriptors of the microbial diversity and that viral infection and resource competition would have opposing effects on a given bacterial assemblage, in which all constituting members are equally sensitive to viral infection. These conditions may occur, but we believe that they are not characteristic of the world's aquatic systems at any given time or location. In our short-term experiments (i.e. $\leq 1$ bacterial net generation time), the most abundant prokaryotic groups remained quantitatively dominant in all treatments, with increasing competitive ability of the minor groups for resources in the presence of viruses and grazers and stronger grazer effects on the prokaryotic size structure than on the abundances of different phylotypes. Grazers and viruses may thus act in synergy and as a significant source of the limiting resources for the development of the less abundant prokaryotic groups (i.e. the loser?). However, the results of such a simplified and short-term experiment should be extrapolated to nature with care. Clearly, additional studies are needed to fully assess the seasonal and long-term interactions between grazers, bacteria and viruses, as well as their ecological significance for the microbial community structure and their function in aquatic ecosystems.

Acknowledgements. A.S.P.R. was supported by a postdoctoral fellowship from the French Government (Ministry of Youth, National Education and Research). The study was partly supported by the French national program ACI/FNS 'ECCO' (VIRULAC research grant awarded to T.S.N.). We thank C. Portelli, D. Boucher, D. Debroas and A. Thenot for their logistic, technical and field assistance.

\section{LITERATURE CITED}

Amann R, Binder BJ, Olson RJ, Chisholm SW, Devereux R, Stahl DA (1990) Combination of 16S rRNA-targeted oligonucleotide probes with flow cytometry for analysing mixed microbial populations. Appl Environ Microbiol 56: 1919-1925

APHA (American Public Health Association) (1985) Standard methods for the examination of water and wastewater, 16th edn. APHA, Washington, DC

Bettarel Y, Sime-Ngando T, Amblard C, Dolan J (2004) Viral activity in two contrasting lake ecosystems. Appl Environ Microbiol 70:2941-2951

Bettarel Y, Sime-Ngando T, Amblard C, Bouvy M, Arfi R (2005) Low consumption of virus-sized particles by heterotrophic nanoflagellates in two lakes of the French Massif Central. Aquat Microb Ecol 39:205-209

Bratbak G, Thingstad F, Heldal M (1994) Viruses and the microbial loop. Microb Ecol 28:209-221

Brinkmeyer R, Glöckner FO, Helmke E, Amann R (2004) Predominance of $\beta$-proteobacteria in summer melt pools on 
Arctic pack ice. Limnol Oceanogr 49:1013-1021

Fuhrman JA (1999) Marine viruses: biogeochemical and ecological effects. Nature 399:541-548

Fuhrman JA, Azam F (1982) Thymidine incorporation as a measure of heterotrophic bacterioplankton production in marine surface waters: evaluation and field results. Mar Biol 66:109-120

Fuhrman JA, Noble RT (1995) Viruses and protists cause similar bacterial mortality in coastal water. Limnol Oceanogr 40:1236-1242

Glöckner FO, Amann R, Alfreider A, Pernthaler J, Psenner R, Trebesius K, Schleifer KH (1996) An in situ hybridization protocol for detection and identification of planktonic bacteria. Syst Appl Microb 19:403-406

Glöckner FO, Fuchs BM, Amann R (1999) Bacterioplankton compositions of lakes and oceans: a first comparison based on fluorescence in situ hybridization. Appl Environ Microbiol 65:3721-3726

Glöckner FO, Zaichikov E, Belkova N, Denissova L, Pernthaler J, Pernthaler A, Amann R (2000) Comparative 16S rRNA analysis of lake bacterioplankton reveals globally distributed phylogenetic clusters including an abundant group of actinobacteria. Appl Environ Microbiol 66: 5053-5065

Gonzales JM, Suttle CA (1993) Grazing by marine nanoflagellates on viruses and virus-sized particles: ingestion and digestion. Mar Ecol Prog Ser 94:1-10

Hahn MW, Höfle MG (2001) Grazing of protozoa and its effect on populations of aquatic bacteria. FEMS Microb Ecol 35: 113-121

Hornak K, Masin M, Jezbera J, Bettarel Y, Nedoma J, SimeNgando T, Šimek K (2005) Effects of decreased resource availability, protozoan grazing and viral impact on the structure of a bacterioplankton assemblage in a canyonshaped reservoir. FEMS Microb Ecol 52:315-327

Jardillier L, Basset M, Domaizon I, Belan A, Amblard C, Richardot M, Debroas D (2004) Bottom-up and top-down control of the bacterial community composition in the euphotic zone of a reservoir. Aquat Microb Ecol 35: 259-273

Jugnia JB, Tadonléké RD, Sime-Ngando $T$, Devaux J, Andrivon C (1999) Bacterial population dynamics, production and heterotrophic activity in a recently formed reservoir. Can J Microbiol 45:747-753

Kirchman DL (2002) The ecology of Cytophaga-Flavobacteria in aquatic environments. FEMS Microb Ecol 39:91-100

Lagenheder S, Jürgens K (2001) Regulation of bacterial biomass and community structure by metazoan and protozoan predation. Limnol Oceanogr 46:121-134

Manz W, Amann R, Ludwig W, Wagner M, Schleifer KH (1992) Phylogenic oligodeoxynucleotide probes for the major subclasses of proteobacteria: problems and solutions. Syst Appl Microbiol 15:593-600

Manz W, Amann R, Ludwig W, Vancanneyt M, Schleifer KH (1996) Application of a suite of 16S rRNA-targeted oligonucleotide probes designed to investigate bacteria of the phylum Cytophaga-Flavobacterium-Bacteroides in the natural environment. Microbiology 142:1097-1106

Nagata T (2000) Production mechanisms of dissolved organic matter. In: Kirchman DL (ed) Microbial ecology of the oceans. Wiley-Liss, New York, p 121-152

Noble RT, Fuhrman JA (1998) Use of SYBR Green I for rapid epifluorescence counts of marine viruses and bacteria. Aquat Microb Ecol 14:113-118

Pedrós-Alió C, Calderon-Paz JI, Gasol JM (2000) Comparative analysis shows bacterivory, not viral lysis, controls the abundance of heterotrophic prokaryotic plankton. FEMS
Microb Ecol 32:157-165

Pernthaler A, Preston CM, Pernthaler J, Delong EF, Amann R (2002) Comparison of fluorescently labeled oligonucleotide and polynucleotide probes for the detection of pelagic marine bacteria and Archea. Appl Environ Microbiol 68:661-667

Posch T, Šimek K, Vbra J, Pernthaler S, Nedoma J, Sattler B, Sonntag B, Psenner R (1999) Predator-induced changes of bacterial size-structure and productivity studied on an experimental microbial community. Aquat Microb Ecol 18: $235-246$

Pradeep Ram AS, Boucher D, Sime-Ngando T, Debroas D, Romagoux JC (2005) Phage bacteriolysis, protistan bacterivory potential, and bacterial production in a freshwater reservoir: coupling with temperature. Microb Ecol 50: $64-72$

Schwalbach MS, Hewson I, Fuhrman JA (2004) Viral effects on bacterial community composition in marine plankton microcosms. Aquat Microb Ecol 34:117-127

SCOR-UNESCO (Scientific Committee on Oceanic ResearchUnited Nations Educational, Scientific and Cultural Organisation) (1966) Determination of photosynthetic pigments in sea water. UNESCO, Paris, p 1-69

Sime-Ngando T, Bettarel Y, Chartogne C, Sean K (2003) The imprint of wild viruses on freshwater microbial ecology. Recent Res Dev Microbiol 7:481-497

Šimek K, Kojecka P, Nedoma J, Hartman P, Vrba J, Dolan J (1999) Shifts in bacterial community composition associated with different microzooplankton size fractions in a eutrophic reservoir. Limnol Oceanogr 44:1634-1644

Šimek K, Armengol J, Comerma M, Garcia JC, Kojecka P, Nedoma J, Hejzlar J (2001a) Changes in the epilimnetic bacterial community composition, production and protists induced mortality along the longitudinal axis of a highly eutrophic reservoir. Microb Ecol 42:359-371

Šimek K, Pernthaler J, Weinbauer MG, Hornak K, Dolan J, Nedoma J, Masin M, Amann R (2001b) Changes in bacterial community composition and dynamics and viral mortality rates associated with enhanced flagellate grazing in mesotrophic reservoir. Appl Environ Microbiol 67: $2723-2733$

Šimek K, Hornak K, Masin M, Christaki U, Nedoma J, Weinbauer MG, Dolan JR (2003) Comparing the effects of resource enrichment and grazing on a bacterioplankton community of a meso-eutrophic reservoir. Aquat Microb Ecol 31:123-135

Stahl DA, Amann R (1991) Development and application of nucleic acid probes. In: Stackebrandt E, Goodfellow M (eds) Nucleic acid techniques in bacterial systematics. John Wiley and Sons, Chichester, p 205-248

Steward GF, Smith DC, Azam F (1996) Abundance and production of bacteria and viruses in the Bering and Chukchi Seas. Mar Ecol Prog Ser 131:287-300

Strom SL (2000) Bacterivory: interactions between bacteria and their grazers. In: Kirchman DL (ed) Microbial ecology of the oceans. Wiley-Liss, New York, p 351-386

Tadonléké DR, Sime-Ngando T, Amblard C, Sargos D, Devaux J (2000) Primary productivity in a recently flooded reservoir. J Plankton Res 21:179-199

Tadonléké DR, Jugnia LB, Sime-Ngando T, Devaux J, Romagoux JC (2002) Food web structure in the recently flooded Sep Reservoir as inferred from phytoplankton dynamics and living microbial biomass. Microb Ecol 43: $67-81$

Thingstad TF (2000) Elements of a theory for the mechanisms controlling abundance, diversity, and biogeochemical role of lytic bacterial viruses in aquatic systems. Limnol 
Oceanogr 45:1320-1328

Thingstad TF, Lignell R (1997) Theoretical models for the control of bacterial growth rate, abundance, diversity and carbon demand. Aquat Microb Ecol 13:1927

Weinbauer MG (2004) Ecology of prokaryotic viruses. FEMS Microbiol Rev 28:127-181

Weinbauer M, Höfle MG (1998a) Significance of viral lysis and flagellate grazing as factors controlling bacterioplankton production in a eutrophic lake. Appl Environ Microbiol 64:431-438

Weinbauer M, Höfle MG (1998b) Size-specific mortality of lake bacterioplankton by natural virus communities. Aquat Microb Ecol 59:431-438

Weinbauer MG, Peduzzi P (1995) Significance of viruses versus heterotrophic nanoflagellates for controlling bacterial abundance in the northern Adriatic Sea. J Plankton Res 17:1851-1856

Weinbauer MG, Rassoulzadegan F (2004) Are viruses driving prokaryotic diversification and diversity? Environ Microbiol 6:1-11

Weinbauer MG, Winter C, Höfle MG (2002) Reconsidering

Editorial responsibility: John Dolan,

Villefranche-sur-Mer, France transmission electron microscopy based estimates of viral infection of bacterioplankton using conversion factors derived from natural communities. Aquat Microb Ecol 27: 103-110

Weinbauer MG, Christaki U, Nedoma J, Šimek K (2003) Comparing the effects of resource enrichment and grazing on viral production in a mesoeutrophic reservoir. Aquat Microb Ecol 31:137-144

Weiss G, Schweitzer B, Amann R, Simon M (1996) Identification in situ and dynamics of bacteria on limnetic organic aggregates. Appl Environ Microbiol 62:1998-2005

Wetzel RG, Likens GE (1995) Limnological analysis, 2nd edn. Springer-Verlag, New York

Wilhelm SW, Suttle CA (1999) Viruses and nutrient cycles in the sea. BioScience 49:781-788

Winter C, Smit A, Herndl GJ, Weinbauer MG (2004) Impact of virioplankton on archaeal and bacterial community richness as assessed in seawater batch cultures. Appl Environ Microbiol 70:804-813

Wommack KE, Colwell RR (2000) Virioplankton: viruses in aquatic ecosystems. Microbiol Mol Biol Rev 64:69-114

Submitted: March 11, 2005; Accepted: August 22, 2005

Proofs received from author(s): October 31, 2005 